\title{
Struktur Komunitas Hymenoptera Parasitoid Pada Berbagai Lanskap Pertanian Di Sumatra Barat
}

\author{
YAHERWANDI \\ Dosen Fakultas Pertanian Universitas Andalas Padang \\ (diterima Desember 2008, disetujui Maret 2009)
}

\begin{abstract}
Community Structure of Parasitic Hymenoptera in West Sumatra Landscape. Understanding how the landscape structure affect the interaction between crops, pests and their natural enemies is a complex problem that can significantly impact on the success or failure of insect biological control. Hymenoptera parasitoids are particularly important natural enemies because of their great diversity and effectiveness as agents of biological control. The objective of this research is to study the diversity of Hymenoptera parasitoid on some vegetables and rice ecosystem in West Sumatera. Hymenoptera parasitoids were sampled using three trapping techniques (farmcop, insect net and yellow pan trap). Species accumulative curves, Jackknife-1 estimator, and indices of diversity were applied to analyze the data. Results indicated that there were 1522 specimen consist of 22 families and 148 species of Hymenoptera parasitoid on agricultural ecosystem in west Sumatera. Braconidae and Ichneumonidae were dominant Hymenoptera parasitoid family in vegetables ecosystem. Contrast, Mymaridae, Diapriidae, and Eulophidae were dominance of Hymenoptera parasitoid famili in rice ecosystem. Diversity of Hymenoptera parasitoid was influenced by the landscape structure. Species richness and diversity were higher in polyculture ecosystem than monoculture.
\end{abstract}

KEY WORDS: Monoculture, polyculture, Hymenoptera, parasitoid, landscape

\section{PENDAHULUAN}

Pada lanskap pertanian moderen struktur spasial, keanekaragaman habitat dan komposisi habitat sangat bervariasi dari satu lanskap ke lanskap yang lain (Marino \& Landis 2000; Kruess 2003). Lanskap pertanian yang sangat sederhana hanya terdiri dari satu jenis ekosistem (monokultur) dan habitat tumbuhan liar, sedangkan lanskap pertanian yang kompleks tidak hanya terdiri dari berbagai ekosistem (polikultur), tetapi juga terdapat banyak habitat tumbuhan liar (Marino \& Landis 1996; Menalled et al. 1999). Ekosistem pertanian di Sumatera Barat mempunyai struktur lanskap yang bervariasi dari yang sederhana sampai yang kompleks. Lanskap pertanian yang sederhana hanya terdiri dari ekosistem padi dan tumbuhan liar atau ekosistem sayuran dan tumbuhan liar (ekosistem monokultur), sedangkan 
lanskap pertanian yang kompleks terdiri dari ekosistem padi, sayuran, palawija dan berbagai habitat tumbuhan liar (ekosistem polikultur).

van Emden (1990) mengatakan peningkatan keanekaragaman struktur lanskap pertanian dapat meningkatkan keanekaragaman serangga hama dan serangga bermanfaat yang berperan menekan kerusakan tanaman oleh hama berkurang. Selanjutnya Kruess \& Tscharntke (2000) menambahkan bahwa tipe dan kualitas habitat, susunan spasial dan hubungan (connectivity) antar habitat di dalam suatu lanskap dapat mempengaruhi keanekaragaman hayati dan fungsi ekosistem. Hipotesis tersebut didukung oleh Marino \& Landis (2000) bahwa keanekaragaman struktur lanskap pertanian tidak hanya mempengaruhi keanekaragaman musuh alami di pertanaman, tetapi juga kelimpahan dan keefektifannya. Selanjutnya Kruess (2003) memperkuat hipotesis tersebut, dengan mengemukakan hasil penelitiannya yaitu kekayaan spesies dan laju parasitisme parasitoid dari Melanogromyza aeneoventris (Diptera: Agromyzidae) meningkat dengan meningkatnya keanekaragaman habitat di dalam lanskap. Hasil yang sama juga ditemukan oleh Yaherwandi et al. (2007) yang melaporkan keanekaragaman Hymenoptera lebih tinggi pada lanskap pertanian yang kompleks yang terdiri dari pertanaman padi, sayuran, palawija dan habitat tumbuhan liar daripada lanskap sederhana yang hanya tediri dari pertanaman padi (padi monokultur). Memahami bagaimana struktur lanskap mempengaruhi interaksi antara tanaman, hama dan musuh alami merupakan masalah yang kompleks dan pada akhirnya mempengaruhi kesuksesan dan kegagalan pengendalian hayati (Landis 1994).

$$
\text { Hymenoptera }
$$
parasitoid merupakan salah satu kelompok serangga yang kaya spesies. Dari 38 famili Hymenoptera yang ditemukan pada ekosistem padi, 28 famili diantaranya adalah Hymenoptera parasitoid (Yaherwandi et al. 2007). Hal ini menunjukan bahwa Hymenoptera parasitoid sangat umum dan berlimpah pada ekosistem teresterial dan kebanyakan spesiesnya berkembang sebagai parasitoid penting berbagai serangga hama tanaman pertanian (LaSalle \& Gauld 1993).

Sayangnya, sampai saat ini penelitian Hymenoptera parasitoid masih terkonsentrasi pada taksonomi dan biologi parasitoid serangga hama tertentu (outekologi), akan tetapi data tentang keanekaragaman, kelimpahan dan komposisi spesies Hymenoptera parasitoid (sinekologi) yang berhubungan dengan perubahan struktur lanskap sangat terbatas. Padahal studi tentang pengaruh struktur lanskap terhadap Hymenoptera parasitoid dapat memberikan informasi untuk pengelolaan lanskap pertanian yang 
lebih baik dan berkelanjutan. Oleh karena itu, kajian keanekaragaman spesies pada skala lanskap dianggap penting karena berpengaruh terhadap peran parasitoid dalam ekosistem yang pada akhirnya dikaji fungsinya untuk menekan serangga hama. Selain itu, strategi Pengendalian Hama Terpadu (PHT) belum ditumpukan pada penggunaan pengendalian hayati secara alami, oleh karena itu informasi tentang keanekaragaman serangga terutama Hymenoptera parasitoid pada struktur lanskap pertanian berbeda merupakan informasi yang sangat diperlukan dalam perencanaan PHT ke depan. Penelitian ini bertujuan untuk mempelajari pengaruh struktur lanskap terhadap komposisi, keanekaragaman, kelimpahan, distribusi dan estimasi kekayaan spesies Hymenoptera parasitoid yang mendiami berbagai ekosistem pertanian di Sumatera Barat dan membandingkan keefektifan beberapa alat yang digunakan untuk koleksi Hymenoptera parasitoid.

\section{BAHAN DAN METODE}

\section{Lokasi penelitian}

Penelitian dilakukan pada tiga lokasi dengan struktur lanskap pertanian yang berbeda. Kota Padang dengan ketinggian 10-20 meter di atas permukaan laut (m.dpl) mempunyai struktur lanskap pertanian yang sederhana yaitu pertanaman padi monokultur. Alahan Panjang yang terletak pada ketinggian 1.300 m.dpl terdiri atas pertanaman sayuran (bawang merah) monokultur. Koto Baru dengan ketinggian 850 m.dpl mewakili lanskap pertanian yang kompleks, yaitu ekosistem padi, sayuran, palawija dan tumbuhan liar. Penelitian dilakukan dari bulan Februari sampai November 2007.

\section{Pelaksanaan penelitian}

Pada masing-masing lokasi ditentukan satu lanskap pertanian. Pada tiap lanskap dibuat satu jalur transek dengan panjang lebih kurang $1000 \mathrm{~m}$ pada sepanjang pertanaman yang ada. Sepanjang jalur transek ditentukan titik pengambilan contoh yang berjarak $100 \mathrm{~m}$ dan terdapat 10 titik sampel. Pengambilan contoh pada ekosistem sayuran dan habitat tumbuhan liar bersamaan dengan pengambilan contoh pada pertanaman padi yaitu awal musim tanam, fase pertumbuhan vegetatif dan fase pertumbuhan generatif. Hal ini berdasarkan pertimbangan keadaan pertanaman dan pola tanam di lapangan. Pola tanam padi di lapangan lebih teratur/serempak daripada pertanaman sayuran.

Pengambilan contoh serangga pada setiap titik contoh pada jalur transek dilakukan dengan menggunakan mesin pengisap serangga farmcop, jaring ayun dan nampan kuning. Farmcop terbuat dari mesin pengisap debu (vacum cleaner) yang dilengkapi dengan aki, kabel, selang dan wadah penampung serangga (Heong et al. 
1991; Schonenly et al. 1998 dan Yaherwandi et al. 2007). Pengambilan contoh serangga dengan farmcop dilakukan dengan menyungkup tanaman terlebih dahulu dengan kurungan kain kasa berbingkai (alas 50 x $50 \mathrm{~cm}$ dan tinggi $90 \mathrm{~cm}$ ), kemudian dihisap dengan farmcop selama 5 menit untuk setiap titik contoh (Heong et al. 1991).

Jaring ayun berbentuk kerucut, mulut jaring terbuat dari kawat melingkar berdiameter $30 \mathrm{~cm}$ dan jaring terbuat dari kain kasa. Pengambilan contoh serangga setiap titik contoh dilakukan dengan mengayunkan jaring ke kiri dan ke kanan secara bolak balik sebanyak 20 kali sambil berjalan.

Nampan kuning terbuat dari wadah plastik yang berukuran alas $15 \times 25 \mathrm{~cm}$ dan tinggi $7 \mathrm{~cm}$. Nampan kuning dipasang di tempat terbuka agar mudah terlihat oleh serangga. Serangga yang tertarik warna kuning akan mendatangi nampan tersebut. Untuk membunuh serangga yang hinggap pada nampan, terlebih dahulu ke dalam nampan dimasukkan larutan air sabun. Air sabun digunakan untuk mengurangi tegangan permukaan, sehingga serangga yang masuk akan tenggelam dan akhirnya mati. Setiap titik contoh dipasang satu nampan dan dibiarkan selama 24 jam. Serangga yang tertangkap dengan farmcop, jaring ayun dan nampan kuning dibersihkan dari kotoran. Selanjutnya disimpan dalam tabung film berisi alkohol 70\% untuk diidentifikasi di laboratorium (Yaherwandi et al. 2007)

Identifikasi serangga dilakukan di Laboratorium Bioekologi Serangga Jurusan Hama dan Penyakit Tumbuhan Fakultas Pertanian, Universitas Andalas. Semua serangga yang diperoleh dipisahkan berdasarkan Ordonya. Khusus bagi ordo Hymenoptera parasitoid, identifikasi dilanjutkan sampai tingkat famili dan morfospesies dengan cara memberikan kode yang berbeda pada individuindividu yang secara morfologi berbeda jenis (hanya diberi kode). Identifikasi serangga untuk tingkat famili dilakukan dengan mengacu buku Goulet \& Huber (1993) dan Noyes (2003).

\section{Analisis data}

Keanekaragaman dan kelimpahan morfospesies Hymenoptera parasitoid dianalisis dengan menggunakan Indeks Keanekaragaman Shannon-Wienner, kemerataan morfospesies dianalisis dengan indeks kemerataan Simpson (Magurran 1996; Spellerberg 1995; Krebs 1999) menggunakan program Ecological metodology 2nd edition (Krebs 2000).

Untuk membuat kurva akumulasi morfospesies, jumlah morfospesies yang diperoleh pada setiap titik sampel diacak sebanyak 50 kali dengan program EstimateSWin $8.00 \quad$ (Cowell 2006). Dari hasil pengacakkan tersebut diperoleh nilai estimasi kekayaan 
spesies Hymenoptera parasitoid berdasarkan Jackknife-1 estimator untuk setiap lanskap (Colwell \& Coddington 1994; Cowell 2006).

\section{HASIL DAN PEMBAHASAN} Komunitas Hymenoptera parasitoid

Jumlah keseluruhan Hymenoptera parasitoid yang telah dikumpulkan pada ekosistem padi dan sayuran di Sumatera Barat adalah 1522 individu yang termasuk dalam 22 famili dan
148 spesies. Jumlah famili yang dikumpulkan ini jika dibandingkan dengan pertanaman padi di Philipina dan Cianjur Jawa Barat berturut-turut jumlahnya lebih sedikit yaitu 31 dan 26 famili (Heong et al. 1991; Yaherwandi et al. 2007). Kelimpahan dan jumlah spesies Hymenoptera parasitoid yang telah dikoleksi pada ekosistem sayuran polikultur lebih tinggi daripada sayuran dan padi monokultur (Tabel 1).

Tabel 1. Jumlah individu, spesies, dan famili Hymenoptera parasitoid pada beberapa ekosistem pertanian di Sumatera Barat

\begin{tabular}{lcccccc}
\hline \hline \multirow{2}{*}{ Famili } & \multicolumn{2}{c}{ Sayuran monokultur } & \multicolumn{2}{c}{ Sayuran polikultur } & \multicolumn{2}{c}{ Padi monokultur } \\
\cline { 2 - 7 } & $\begin{array}{c}\text { jumlah } \\
\text { individu }\end{array}$ & $\begin{array}{c}\text { jumlah } \\
\text { spesies }\end{array}$ & $\begin{array}{c}\text { jumlah } \\
\text { individu }\end{array}$ & $\begin{array}{c}\text { jumlah } \\
\text { spesies }\end{array}$ & $\begin{array}{c}\text { jumlah } \\
\text { individu }\end{array}$ & $\begin{array}{c}\text { jumlah. } \\
\text { spesies }\end{array}$ \\
\hline Betylidae & 0 & 0 & 5 & 1 & 1 & 1 \\
Braconidae & 205 & 13 & 189 & 16 & 9 & 6 \\
Calcididae & 4 & 2 & 0 & 0 & 0 & 0 \\
Ceraphronidae & 0 & 0 & 3 & 1 & 0 & 0 \\
Diapriidae & 1 & 1 & 30 & 4 & 48 & 4 \\
Dryinidae & 0 & 0 & 0 & 0 & 1 & 1 \\
Encyrtidae & 2 & 1 & 21 & 3 & 7 & 3 \\
Eucoilidae & 16 & 5 & 51 & 4 & 4 & 2 \\
Eulophidae & 10 & 4 & 64 & 9 & 55 & 10 \\
Evaniidae & 0 & 0 & 8 & 1 & 0 & 0 \\
Halictidae & 0 & 0 & 4 & 1 & 36 & 1 \\
Ichneumonidae & 107 & 16 & 109 & 16 & 13 & 8 \\
Megaspilidae & 3 & 1 & 4 & 1 & 0 & 0 \\
Mutillidae & 0 & 0 & 6 & 1 & 0 & 0 \\
Mymaridae & 0 & 0 & 20 & 3 & 84 & 5 \\
Mymarommatidae & 0 & 0 & 16 & 1 & 0 & 0 \\
Platigastridae & 0 & 0 & 6 & 1 & 0 & 0 \\
Pteromalidae & 2 & 2 & 40 & 4 & 5 & 3 \\
Scelionidae & 11 & 4 & 94 & 12 & 42 & 12 \\
Stenotritidae & 0 & 0 & 4 & 1 & 0 & 0 \\
Torymidae & 1 & 1 & 4 & 1 & 0 & 0 \\
Trichogrammatidae & 0 & 0 & 9 & 3 & 25 & 3 \\
\hline Total & 362 & 50 & 687 & 84 & 330 & 59 \\
\hline
\end{tabular}


Hasil ini mirip dengan yang ditemukan oleh Settle et al. (1996) yaitu kelimpahan dan jumlah spesies parasitoid lebih tinggi pada ekosistem padi polikultur di Jawa Tengah daripada padi monokultur di Pantura (Jawa Barat). Hole et al. (2005) yang mereview 20 artikel yang membandingkan kelimpahan dan kekayaan spesies musuh alami pada sistem pertanian polikultur dengan sistem monokultur, 14 artikel diantaranya mendukung hasil penelitian ini.

Dari 22 famili Hymenoptera parasitoid yang telah dikumpulkan, dua famili yaitu Braconidae dan Ichneumonidae adalah famili yang mempunyai kelimpahan relatif tertinggi $(>15 \%)$ atau paling dominan pada ekosistem sayuran monokultur dan polikultur (Gambar 1). Sebelumnya Yaherwandi (2006) juga menemukan hal sama dengan hasil penelitian ini yaitu Diadegma sp (Ichneumonidae) dan Apanteles sp (Braconidae) adalah famili Hymenoptera parasitoid yang dominan pada ekosistem sayuran di Sumatera Barat yang didominasi oleh tanaman Cruciferae.

Sebaliknya, pada ekosistem padi monokultur famili Hymenoptera parasitoid yang dominan adalah Mymaridae, Eulophidae, dan Diapriidae (Gambar 1). Hasil penelitian ini mirip dengan yang dilaporkan Heong et al. (1991) dan Yaherwandi \& Syam (2007) bahwa
Diapriidae, Eulophidae, Mymaridae, Scelionidae dan Trichogrammatidae merupakan famili yang dominan pada pertanaman padi. Hal ini karena sebagian besar spesies dari familifamili tersebut merupakan parasitoid dari serangga hama padi dari ordo Homoptera seperti wereng batang, wereng daun, ordo Lepidoptera seperti penggerek batang dan ulat pemakan daun (Heong et al. 1991; Yaherwandi \& Syam 2007).

Keanekaragaman habitat dan struktur lanskap pertanian berpengaruh terhadap kekayaan, kemerataan, dan keanekaragaman spesies Hymenoptera parasitoid. Keanekaragaman spesies Hymenoptera parasitoid lebih tinggi di ekosistem sayuran polikultur daripada ekosistem sayuran dan padi monokultur, sedangkan keanekaragaman spesies di ekosistem sayuran dan monokultur tidak berbeda jauh (Tabel 2). Hal ini karena struktur lanskap pertanian kedua eksositem tersebut hampir sama yaitu padi dan sayuran monokultur, sehingga kekayaan dan kemerataan spesies Hymenoptera parasitoid kedua ekosistem tersebut tidak jauh berbeda dibandingkan dengan ekosistem sayuran polikultur. Nilai keanekaragaman spesies adalah penggabungan hasil dari nilai kekayaan dan kemerataan spesies. 

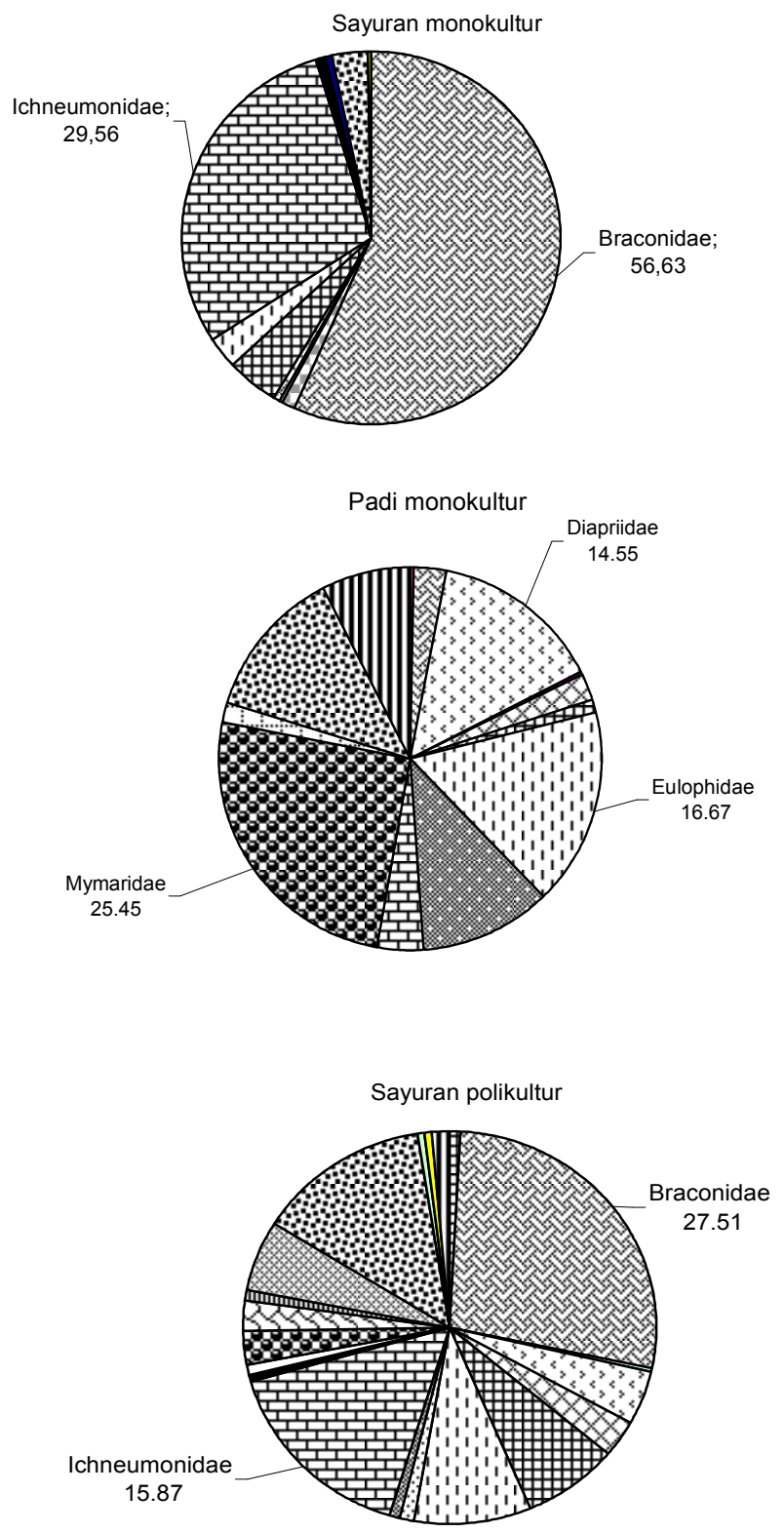

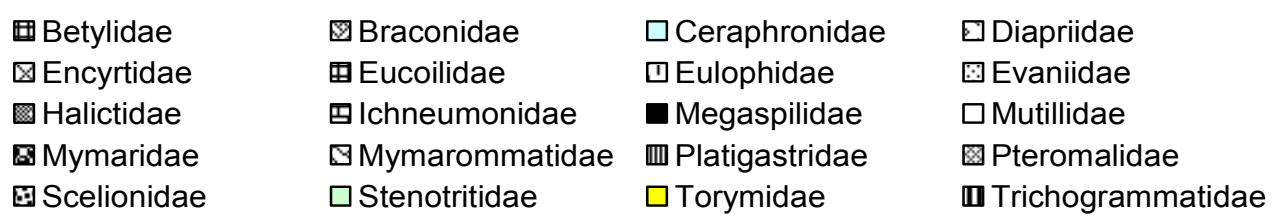

Gambar 1. Kelimpahan relatif tiap famili Hymenoptera parasitoid pada beberapa ekosistem pertanian di Sumatera Barat 
Tabel 2. Kekayaan, kemerataan, dan keanekaragaman spesies Hymenoptera parasitoid pada ekosistem sayuran monokultur, sayuran polikultur, dan padi monokultur di Sumatera Barat

\begin{tabular}{lccc}
\hline \hline \multicolumn{1}{c}{ Ekosistem } & Kekayaan spesies & Kemerataan sesies & Keanekaragaman spesies \\
\hline Sayuran monokultur & 57 & 0.17 & 4.26 \\
Sayuran & & & \\
Polikultur & 101 & 0.40 & 6.00 \\
Padi monokultur & 67 & 0.29 & 4.98 \\
\hline
\end{tabular}

Tabel 3. Jumlah individu, spesies, dan famili Hymenoptera parasitoid yang dikoleksi dengan Farmcop, jaring ayun, dan nampan kuning pada beberapa ekosistem pertanian di Sumatera Barat

\begin{tabular}{|c|c|c|c|c|c|c|}
\hline \multirow[b]{2}{*}{ Famili } & \multicolumn{2}{|c|}{ Farmcop } & \multicolumn{2}{|c|}{ Jaring ayun } & \multicolumn{2}{|c|}{ Nampan kuning } \\
\hline & $\begin{array}{l}\text { jumlah } \\
\text { individu }\end{array}$ & $\begin{array}{l}\text { jumlah } \\
\text { spesies }\end{array}$ & $\begin{array}{l}\text { jumlah } \\
\text { individu }\end{array}$ & $\begin{array}{l}\text { jumlah } \\
\text { spesies }\end{array}$ & $\begin{array}{l}\text { jumlah } \\
\text { individu }\end{array}$ & $\begin{array}{l}\text { jumlah } \\
\text { spesies }\end{array}$ \\
\hline Betylidae & 6 & 1 & 0 & 0 & 0 & 0 \\
\hline Braconidae & 150 & 14 & 144 & 13 & 109 & 12 \\
\hline Calcididae & 2 & 1 & 1 & 1 & 1 & 1 \\
\hline Ceraphronidae & 3 & 1 & 0 & 0 & 0 & 0 \\
\hline Diapriidae & 10 & 3 & 0 & 0 & 69 & 5 \\
\hline Dryinidae & 0 & 0 & 1 & 1 & 0 & 0 \\
\hline Encyrtidae & 5 & 2 & 6 & 3 & 19 & 4 \\
\hline Eucoilidae & 13 & 5 & 2 & 2 & 56 & 7 \\
\hline Eulophidae & 39 & 10 & 18 & 5 & 72 & 9 \\
\hline Evaniidae & 0 & 0 & 8 & 1 & 0 & 0 \\
\hline Halictidae & 0 & 0 & 40 & 1 & 0 & 0 \\
\hline Ichneumonidae & 88 & 14 & 76 & 16 & 65 & 13 \\
\hline Megaspilidae & 7 & 1 & 0 & 0 & 0 & 0 \\
\hline Mutillidae & 3 & 1 & 3 & 1 & 0 & 0 \\
\hline Mymaridae & 71 & 5 & 0 & 0 & 33 & 4 \\
\hline Mymarommatidae & 2 & 1 & 0 & 0 & 14 & 1 \\
\hline Platigastridae & 0 & 0 & 0 & 0 & 6 & 1 \\
\hline Pteromalidae & 20 & 4 & 14 & 3 & 13 & 3 \\
\hline Scelionidae & 33 & 14 & 24 & 6 & 90 & 13 \\
\hline Stenotritidae & 0 & 0 & 0 & 0 & 4 & 1 \\
\hline Torymidae & 0 & 0 & 1 & 1 & 4 & 1 \\
\hline Trichogrammatidae & 25 & 3 & 0 & 0 & 9 & 4 \\
\hline Total & 477 & 80 & 338 & 54 & 564 & 79 \\
\hline
\end{tabular}

Dengan demikian jelas bahwa tidak berbedanya keanekaragaman spesies pada ekosistem sayuran dan padi polikultur adalah karena kekayaan dan kemerataan spesiesnya juga tidak berbeda.
Ekosistem sayuran polikultur yang terdiri dari berbagai habitat (padi, sayur-sayuran dan tumbuhan liar) membentuk struktur lanskap pertanian yang lebih kompleks daripada ekosistem sayuran dan padi 
monokultur. Habitat-habitat tersebut menyediakan berbagai sumberdaya seperti inang alternatif, makanan serangga dewasa seperti serbuk sari dan nektar, habitat tanaman lain sebagai tempat berlindung, kontinuitas ketersediaan makanan dan iklim mikro yang sesuai bagi kelangsungan hidup dan keanekaragaman parasitoid. Semua sumberdaya tersebut hanya diperoleh pada sistem pertanian yang polikultur (Dryer \& Landis 1996; Dryer \& Landis 1997). Hasil yang sama juga pernah dilaporkan Idris et al. (2002), Hooks \& Johnson (2003), Menalled et al. (2003), Stephens et al. (2006), dan Bianchi et al. (2006) bahwa keanekaragaman parasitoid dipengaruhi oleh tipe lanskap pertanian, yaitu lanskap pertanian dengan struktur yang kompleks memiliki kelimpahan, kekayaan, dan keanekaragaman spesies parasitoid yang lebih tinggi daripada lanskap dengan struktur yang lebih sederhana.

\section{Efektifitas alat koleksi Hymenoptera parasitoid}

Berdasarkan metode atau alat koleksi yang digunakan terdapat perbedaan kelimpahan, spesies, dan famili yang terkumpul untuk tiap-tiap metode. Metode farmcop total jumlah parasitoid yang tertangkap adalah 477 individu, 80 spesies, dan 16 famili (Tabel 3). Metode jaring ayun jumlah individu yang dikoleksi adalah 338 individu, 54 spesies, dan 13 famili (Tabel 3). Metode nampan kuning total jumlah parasitoid yang tertangkap 564 individu, 79 spesies, dan 15 famili (Tabel 3). Metode farmcop dan nampan kuning adalah metode yang paling efektif untuk mengkoleksi Hymenoptera parasitoid pada ekosistem pertanian sayuran dan padi.

Farmcop yang dimodifikasi dari alat pengisap debu berukuran kecil, mudah dibawa, ujung selang pengisap dapat langsung diarahkan ke pangkal tanaman padi dan sayuran menjadi alat yang efektif untuk koleksi Hymenoptera parasitoid yang berukuran kecil seperti parasitoid famili Mymaridae, Trichogramma, dan Scelionidae (Yaherwandi et al. 2007). Nampan kuning juga alat yang efektif untuk koleksi Hymenoptera parasitoid karena banyak Hymenoptera parasitoid yang tertarik terhadap warna kuning, sehingga alat ini cukup efektif digunakan untuk mempelajari keanekaragaman parasitoid (Noyes 1989; Yaherwandi et al. 2007).

\section{Estimasi spesies Hymenoptera parasitoid}

Dari kurva akumulasi spesies terlihat bahwa jumlah keseluruhan spesies yang dikumpulkan pada ketiga ekosistem masih kurang jika dibandingkan dengan estimasi spesies dengan Jacknife-1 estimator (Gambar 2). Menurut Krebs (1999) jumlah 

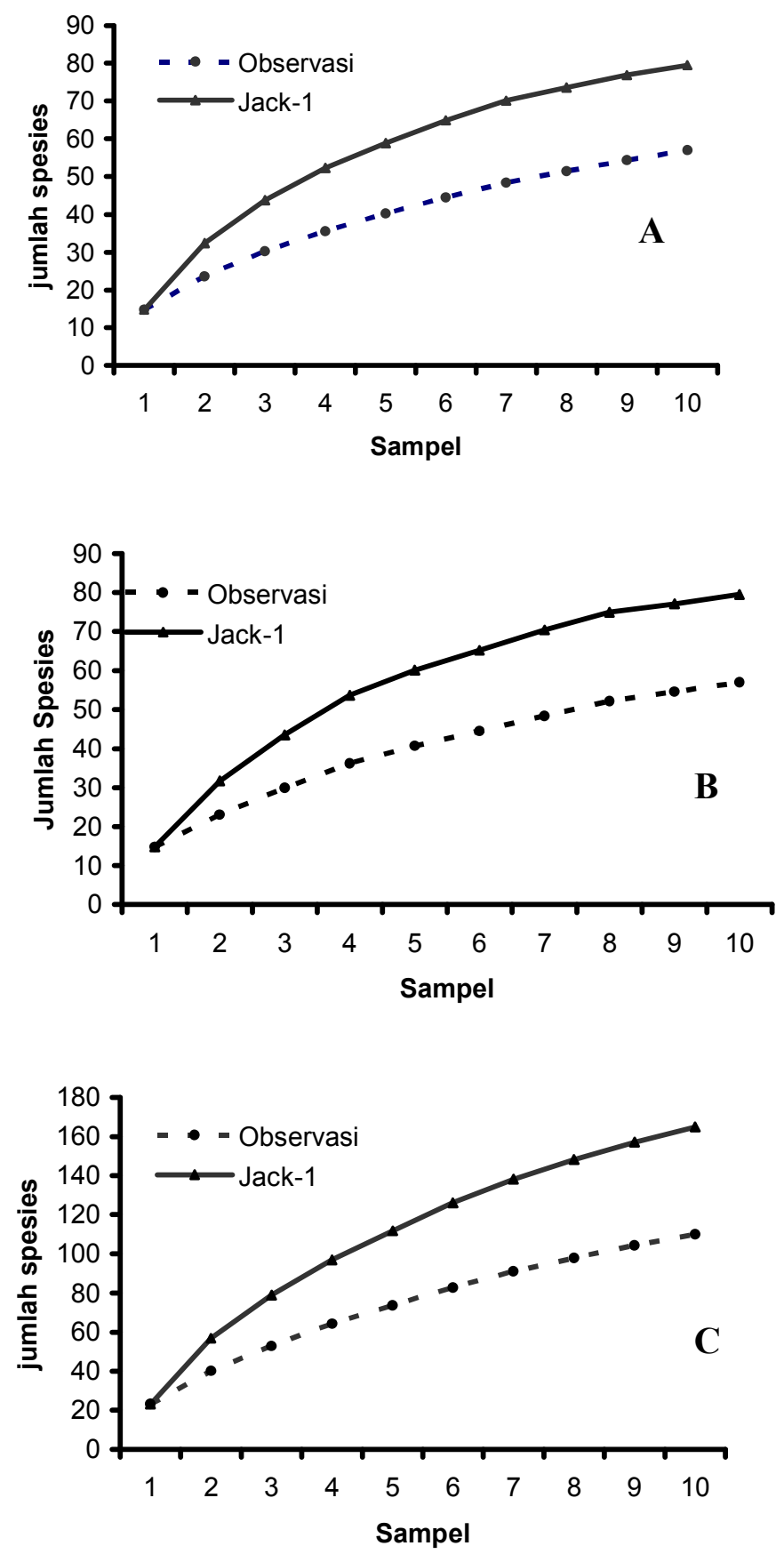

Gambar 2. Kurva akumulasi spesies Hymenoptera parasitoid pada ekosistem sayuran monokultur (A), padi monokultur (B), dan sayuran polikultur (C) berdasarkan data observasi dan estimasi Jacknife estimator dengan program EstimateS Win 8.00 
spesies tertinggi yang diestimasi oleh Jacknife estimator adalah dua kali jumlah spesies yang diperoleh. Selanjutnya dikatakan bahwa Jacknife1 estimator dipengaruhi oleh total jumlah spesies, ukuran sample dan jumlah spesies unik (rare spesies) (Krebs 1999). Dengan demikian, belum optimalnya jumlah spesies Hymenoptera parasitoid yang dikumpulkan kemungkinan disebabkan oleh jumlah sampel (10 sampel per ekosistem) dan alat yang digunakan untuk koleksi serangga belum optimal. Namun demikian, jumlah spesies yang dikumpulkan pada ketiga ekosistem lebih dari $60 \%$ spesies Hymenoptera parasitoid yang ada berdasarkan Jacknife-1 estimator (Gambar 2). Banyak ahli ekologi yang tidak setuju dengan Jackknife estimator diantaranya adalah Heltshe \& Forrester (1983) karena estimasi kekayaan spesies dalam komunitas oleh Jackknife estimator cenderung bias positif atau lebih tinggi (overestimate), tetapi Palmer (1990) menemukan bahwa Jacknife estimator lebih akurat dari delapan estimator lain yang dia gunakan.

\section{KESIMPULAN}

Dari hasil penelitian ini dapat ditarik beberapa kesimpulan yaitu (1) Total jumlah Hymenoptera parasitoid yang telah dikoleksi adalah 1552 individu, 22 famili, dan 148 spesies. (2) Kelimpahan, jumlah spesies, dan famili yang dikoleksi pada ekosistem sayuran polikultur lebih tinggi daripada ekosistem sayuran dan padi monokuler. (3) Famili Braconidae dan Ichneumonidae adalah famili Hymenoptera parasitoid yang dominan baik pada ekosistem sayuran monokultur maupun polikultur, sedangkan pada eksosistem padi monokultur yang dominan adalah Mymaridae, Diapriidae, dan Eulophidae. (4) Kekayaan spesies yang telah dikoleksi pada ekosistem sayuran polikultur, sayuran dan padi monokultur telah mencapai $60 \%$ lebih berdasarkan Jacknife-1 estimator, dan (5) Dari tiga metode koleksi yang digunakan dalam penelitian ini, metode farmcop dan nampan kuning paling efektif untuk mengoleksi Hymenoptera parasitoid.

\section{UCAPAN TERIMA KASIH}

Kami mengucapkan terima kasih kepada Direktur DP2M yang telah mendanai penelitian ini. Ketua Juruasan Hama dan Penyakit Tumbuhan Faperta Unand yang telah memberi izin untuk melaksanakan penelitian ini mahasiswa yang telah terlibat dan membantu penelitian serta kepada semua pihak yang telah membantu baik moril maupun materil dalam pelaksanaan penelitian ini. 


\section{DAFTAR PUSTAKA}

Bianchi FJJA, Booij CJH, Tscharntke T. 2006. Sustainable pest regulation in agriculture landscape: a review on landscape composition, biodiversity and natural pest control. Proc. R. Soc. B 273: $1715-1727$.

Colwell RK, Coddington JA. 1994. Estimating biodiversity terrestrial extrapolation. Philosophical Transactions of Royal Society London 345: 101118.

Colwell RK. 2006. EstimateS: Statistical estimate of spesies richness and shared spesies from samples. Version 8.00. http://www.viceroy.eeb.ucon n.edu/estimates [download 13 Januari 2006].

Dryer LE, Landis DA. 1996. Effect of habitat, temprature and sugar availability on longevity of Eriborus terebrans (Hym: Ichneumonidae). Environ. Entomol. 25: $1192-1201$.

Dryer LE, Landis DA. 1997. influence of non-crop habitat on distribution of Eriborus terebrans (Hym: Ichneumonidae) in cornfields. Environ. Entomol. 26: 924 - 932.

Goulet H, Huber JT. 1993. Hymenoptera of The world: An Identification Guide to Families. Ottawa: Research Branch Agruculture Canada Publication.
JE Heltshe, Forrester NE. 1983. Estimating species richness using the jackknife procedure. Biometrics 39: 111

Heong KL, Aquino GB, Barrion AT. 1991. Arthropod community structure of rice ecosystem in the Philippines. Bulletin of Entomological Research 81: 407-416.

Hole AG, Perkins AJ, Wilson JD, Alexander IH, Grice PV, Evan AD. 2005. Does organic farming benefit biodiversity?. Biological Conservation 122: 113 - 130.

Idris AB, Nor SM, Rohaida R. 2002. Study on diversity of insect community at different altitudes of Gunung Nuang in Selangor, Malaysia. Journal of Biological Sciences 2 (7): $505-507$.

Krebs CJ. 1999. Ecological Metodology. Second Edition. New York: An imprint of Addison Wesley Longman, Inc.

Krebs JC. 2000. Program for ecological methodology [software]. Second Edition. New York: An imprint of Addison Wesley Longman, Inc.

Kruess A, Tschartntke T. 2000. Spesies richness and parasitism in a fragmented landscape: experiments and field studies with insects on vicia sepium. Oecologia 122: 129-137.

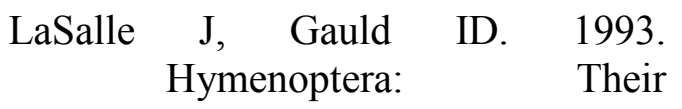


diversity, and their impact on the diversity of other organisms. Di dalam. LaSalle J, Gauld ID, editor. Hymenoptera and Biodiversity. Wallingfor, UK: CAB International. p 1-26.

Magurran AE. 1996. Ecological Diversity and Its Measurement. London: Chapman and Hall.

Marino PC, Landis DA. 2000. Parasitoid community structure: implications for biological control in agricultural landscapes. Di dalam: Ekbon B, Irwin ME, Robert Y, editor. Interchanges of Insects between Agriculturan and Surrounding Landscapes. Boston: Kluwer Academic Publishers.

Menalled FD, Costamagna AC, Marino PC, Landis DA. 1999. Temporal variation in the response of parasitoids to agriculture landscape structure. Agriculture, Ecosystem and environment 96: $29-35$.

Noyes JS. 1989. A study of methods of sampling Hymenoptera (Insecta) in tropical rainforest, with special reference to the parasitica. Journal of Nature History 23: $285-298$

Noyes JS. 2003. Universal Chalcidoidea Database. http://www.nhm.ac.uk/entom ology [donwload 15 Juni 2004].
Palmer MW. 1990. The estimation of species richness by extrapolation . Ecology 71: 1195-1199

Schoenly K, Justo HD, Barrion AT, Harris MK, Bottrell DG. 1998. Analysis of invertebrate biodiversity in a Philipine farmer's irrigated rice field. Environ. Entomol. 21(5): 1125-1136.

Settle WH, Ariawan H, Astuti ET, Cahaya W, Hakim AL, Hindayana D, Lestari AS, \& Fajarningsih. 1996. Managing tropical rice pest through conservation of generalis natural enemies and alternative prey. Ecology 77 (7): $1975-1988$.

van Emden HF. 1990. Plant diversity and natural enemy efficiency in agroecosystems. Di dalam: Mackkauer M, Ehler LE, Roland J, editor. Critical Issues in Biological Control. Great Britain: Atheneum Press. hlm 63-80.

Yaherwandi. 2006. Struktur komunitas Hymenoptera parasitoid pada ekosistem sayuran dan habitat non-crop di Sumatera Barat. Laporan Penelitian Doktor Muda. Lembaga Penelitian Unand. Padang.

Yaherwandi, Manuwoto S, Buchori D, Hidayat P, Budiprasetyo L. 2007. Keanekaragaman Komunitas Hymenoptera Parasitoid pada Ekosistem Padi. Jurnal HPT Tropika vol 7 (1): $10-20$

Yaherwandi, Syam U. 2007. Keanekaragaman dan Biologi 
Reproduksi Parasitoid Telur Wereng coklat Nillaparvata lugens Stall. (Homoptera: Delphacidae) pada Struktur
Lanskap Pertanian Berbeda. Jurnal Acta Agrosia 10 (1): $76-86$ 